\title{
Map: Provinces, Counties and Main Cities
}

Carte: Provinces, comtés et villes principales

\section{(2) OpenEdition}

\section{Journals}

Electronic version

URL: http://journals.openedition.org/rfcb/286

DOI: $10.4000 / \mathrm{rfcb} .286$

ISSN: 2429-4373

\section{Publisher}

CRECIB - Centre de recherche et d'études en civilisation britannique

\section{Printed version}

Date of publication: 1 September 2014

Number of pages: 239

ISSN: 0248-9015

\section{Electronic reference}

"Map: Provinces, Counties and Main Cities », Revue Française de Civilisation Britannique [Online],

XIX-2 | 2014, Online since 01 May 2015, connection on 20 April 2019. URL : http://

journals.openedition.org/rfcb/286 ; DOI : 10.4000/rfcb.286

\section{(c) (†) $\odot$}

Revue française de civilisation britannique est mis à disposition selon les termes de la licence Creative Commons Attribution - Pas d'Utilisation Commerciale - Pas de Modification 4.0 International. 


\section{Map: Provinces, Counties and Main Cities}

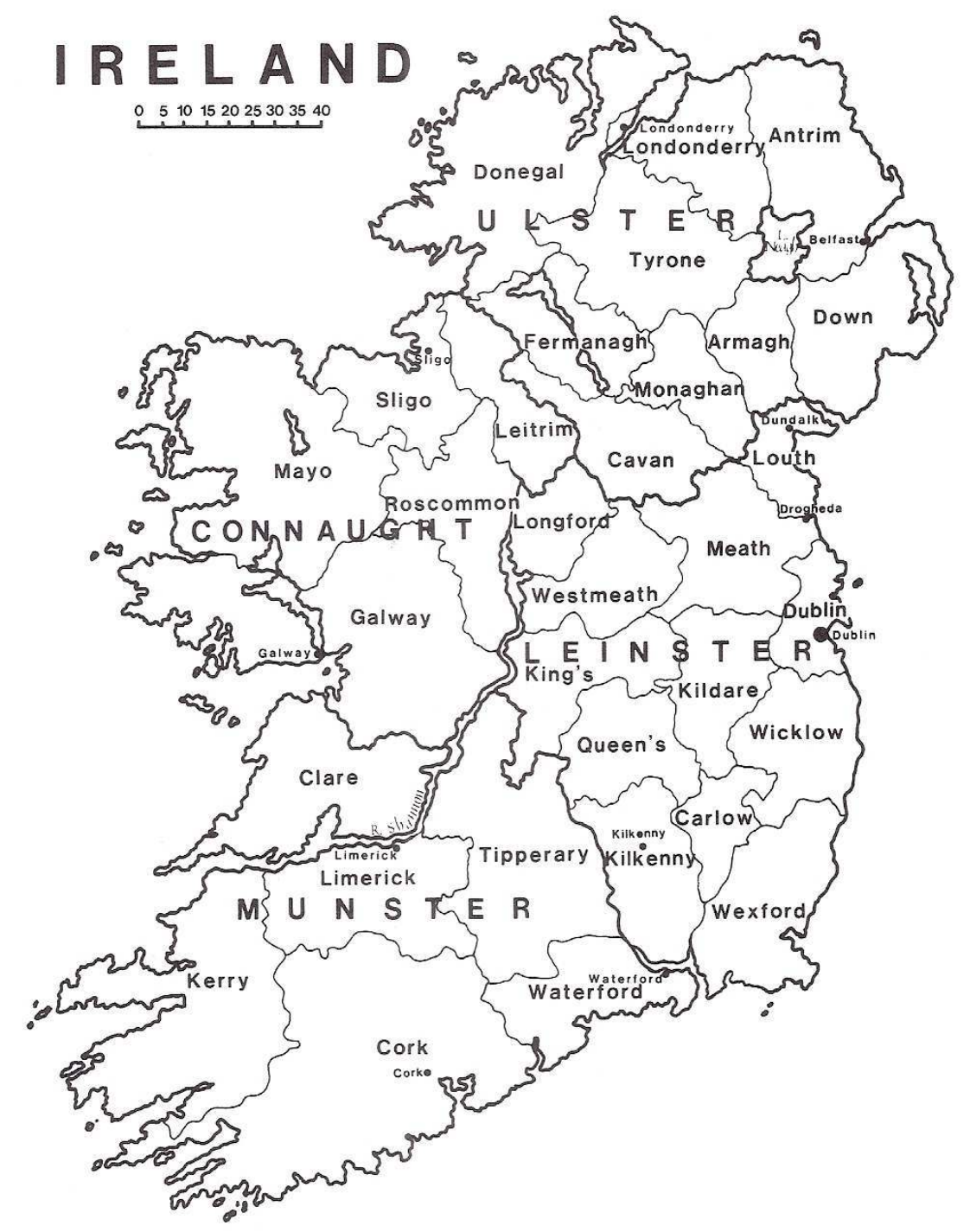

Source : Kerby A. MILLER, Emigrants and Exiles: Ireland and the Irish Exodus to North America, Oxford: Oxford University Press, 1985. 